\title{
RNase E autoregulates its synthesis by controlling the degradation rate of its own mRNA in Escherichia coli: unusual sensitivity of the rne transcript to RNase E activity
}

\author{
Chaitanya Jain and Joel G. Belasco \\ Department of Microbiology and Molecular Genetics, Harvard Medical School, Boston, Massachusetts 02115 USA
}

\begin{abstract}
RNase $E$ is a key regulatory enzyme that appears to control the principal pathway for mRNA degradation in Escherichia coli. Here, we show that RNase E represses its own synthesis by reducing the cellular concentration of the rne (RNase E) gene transcript. Autoregulation is achieved by modulating the longevity of this 3.6-kb mRNA, whose half-life ranges from $<40 \mathrm{sec}$ to $>8 \mathrm{~min}$ depending on the level of RNase $\mathrm{E}$ activity in the cell. Feedback regulation is mediated in cis by the $5^{\prime}$-terminal 0.44-kb segment of rne mRNA, which is sufficient to confer this property onto a heterologous transcript to which it is fused. Like the intact protein, an amino-terminal fragment of RNase E lacking 563 amino acid residues can act in trans to repress rne gene expression. Paradoxically, raising the rne gene copy number 21 -fold in $E$. coli causes an unexpected reduction in the concentration of the full-length rne transcript, yet results in a small increase in RNase $E$ protein production. These surprising phenomena are explained in terms of a model in which the degradation of this long and highly labile mRNA commences before elongation of the nascent transcript has been completed. In such circumstances, gene expression can be unusually sensitive to changes in mRNA stability.
\end{abstract}

[Key Words: RNase E; rne; mRNA degradation; gene regulation; Escherichia coli]

Received September 6, 1994; revised version accepted November 9, 1994.

Messenger RNA (mRNA) degradation is an important mechanism for regulating gene expression in all organisms. The steady-state concentration of a message is as sensitive to its rate of decay as it is to its rate of synthesis, and rates of mRNA decay can differ considerably within a single cell. In Escherichia coli, for example, mRNA half-lives can be as short as a fraction of a minute or as long as half an hour (Belasco 1993). Through their influence on mRNA abundance, these half-life differences have a corresponding effect on protein synthesis (Klug et al. 1987; Newbury et al. 1987).

An important advance in understanding the mechanism of prokaryotic mRNA degradation was the identification of RNase $\mathrm{E}$ as a key ribonuclease controlling mRNA decay in $E$. coli. Cleavage by this endonuclease appears to be a critical step in the degradation of most $E$. coli mRNAs, as the decay rate of bulk mRNA and of many individual transcripts slows when RNase $\mathrm{E}$ is thermally inactivated in $E$. coli strains with a temperaturesensitive mutation in the structural gene for this enzyme (the rne gene, also known as the ams or hmp1 gene) (Apirion 1978; Ono and Kuwano 1979; Mudd et al. 1990; Babitzke and Kushner 1991; Melefors and von Gabain 1991; Taraseviciene et al. 1991). Although RNase E can form a complex with at least three other E. coli proteins, it has been shown that $r n e$-dependent endonuclease activity resides in the $118-\mathrm{kD}$ RNase E polypeptide per se (L.-H. Chen and J.G. Belasco, unpubl.; Cormack et al. 1993; Carpousis et al. 1994). As yet, the RNA structural features that define the cleavage site specificity of this enzyme are not well understood (Ehretsmann et al. 1992; Lin-Chao et al. 1994; McDowall et al. 1994).

RNase E appears to be an essential E. coli gene product, as all $r n e^{t s}$ mutants that are currently available display a temperature-sensitive lethal phenotype (Apirion 1978; Ono and Kuwano 1979|. Furthermore, overexpression of the rne gene on high-copy plasmids slows cell growth and can lead to plasmid loss or the acquisition of me mutations (Claverie-Martin et al. 1991; C. Jain and J.G. Belasco, unpubl.|. Given the importance of RNase E for mRNA metabolism in E. coli and the apparent sensitivity of cells to levels of RNase E activity that are excessively high or low, it would seem reasonable to expect that $E$. coli might have evolved a mechanism for tightly regulating the production of this key ribonuclease. Consistent with this hypothesis, a temperaturesensitive RNase $E$ variant and its cognate mRNA each accumulate to a higher cellular concentration when this 
enzyme is thermally inactivated at $44^{\circ} \mathrm{C}$, and this increase in the abundance of the full-length rne transcript can be reversed by introducing a plasmid clone of a truncated rne gene that is functional at this temperature (Melefors 1991; Mudd and Higgins 1993).

In this study we present evidence that RNase E regulates its own synthesis by controlling the decay rate of rne mRNA, whose half-life can vary by more than a factor of 14 in response to changes in cellular RNase E activity. By deletion mapping, we have identified the domains of the rne transcript and of RNase E that mediate this autoregulatory phenomenon. Our data suggest that the unusual sensitivity of rne gene expression to cellular RNase E activity is the result, in part, of cotranscriptional degradation of nascent rne transcripts, a process that can amplify the impact of mRNA stability changes by influencing both the production and decay of mRNA templates for RNase E synthesis.

\section{Results \\ rne-lacZ fusions are unusually responsive to RNase $E$ activity in vivo}

To assess the ability of RNase $\mathrm{E}$ to regulate $m e$ gene expression, we first constructed a translational fusion in which the promoter, 5 '-untranslated region (UTR), and first 181 codons of the rne gene were joined in-frame to $l a c Z$, and we introduced a single copy of this fusion (ez1) as a $\lambda$ lysogen into the chromosome of a $\mathrm{lacZ}^{-} E$. coli strain. We then determined the effect of RNase $E$ overproduction on expression of the rne-lac $Z$ fusion by comparing $\beta$-galactosidase production from the fusion in $E$. coli cells containing a single, chromosomal copy of the wild-type rne gene versus cells containing a multicopy plasmid clone of the rne gene (pRNE101, a derivative of pACYC177). Overproduction of RNase $E$ in this manner reduces expression of the rne-lacZ fusion by a factor of four (Table 1). Furthermore, expression of this gene fusion is increased when cellular RNase E activity is reduced to below-normal levels by replacing the chromosomal copy of the rne gene with either of two temperature-sensitive rne alleles (me-3071 or ams-1). For example, when a thermolabile form of RNase E is partially inactivated at $37^{\circ} \mathrm{C}$ in ams-1 cells, expression of the $r n e-l a c Z$ fusion increases ninefold to a level that is $\sim 33$ times higher than in the same cells containing a multicopy plasmid clone of the wild-type rne gene. In contrast, RNase E overproduction has almost no effect on the expression of the wild-type $1 a c Z$ gene, a finding that implies that the responsiveness of the rne-lac $Z$ fusion to RNase E overproduction is attributable to its rne component. Together, these data indicate that RNase E can repress the expression of its own gene and that a promoter-proximal rne gene fragment can confer this sensitivity to RNase E overproduction upon an otherwise unresponsive gene to which it is fused. Furthermore, the insensitivity of $1 a c Z$ and two other $1 a c Z$ gene fusions (ompA-lacZ and IS10-lacZ) to RNase E overproduction suggests that the rne gene is unusual in its ability to be repressed by elevated cellular levels of this ribonuclease.

\section{me and me-lacZ transcript levels are dependent on RNase $E$ activity in vivo}

To determine whether the effect of the three rne alleles (wild-type, rne-3071, and ams-1) on expression of the unfused rne gene parallels their effect on expression of the rne-lacZ fusion, total cellular RNA was isolated from isogenic $r n e^{+}$, rne-3071, and ams-1 strains containing an $r n e-l a c Z$ fusion and analyzed by Northern blotting. Two distinct mRNAs were detected by probing the blot with radiolabeled rne DNA: the $3.6-\mathrm{kb}$ transcript of the rne gene and the $4.0-\mathrm{kb}$ transcript of the rne-lacZ fusion

Table 1. Effect of cellular RNase E activity on the expression of rne-lacZ, lacZ, and other lacZ fusions

\begin{tabular}{|c|c|c|c|c|}
\hline \multirow[b]{2}{*}{ Gene fusion } & \multirow{2}{*}{$\begin{array}{l}\text { Chromosomal } \\
\text { rne allele }\end{array}$} & \multicolumn{2}{|c|}{$\beta$-Galactosidase activity (units) ${ }^{2}$} & \multirow{2}{*}{$\begin{array}{l}\text { Repression } \\
\text { ratio }^{\text {b }}\end{array}$} \\
\hline & & pACYC177 & pRNE101 & \\
\hline rne-lacZ & $r n e^{+}$ & $172 \pm 7$ & $47 \pm 3$ & 3.7 \\
\hline me-lacZ & rne-3071 & $591 \pm 18$ & $45 \pm 1$ & 13 \\
\hline me-lacZ & $a m s-1$ & $1574 \pm 23$ & $48 \pm 1$ & 33 \\
\hline $\operatorname{lac} Z$ & ams-1 & $2430 \pm 120$ & $3120 \pm 50$ & 0.78 \\
\hline ompA-1acZ & $a m s-1$ & $84 \pm 2$ & $87 \pm 3$ & 0.97 \\
\hline IS10-lacZ & ams-1 & $3.8 \pm 0.1$ & $6.5 \pm 0.5$ & 0.58 \\
\hline
\end{tabular}

${ }^{a}$ All $\beta$-galactosidase assays were performed on extracts of $E$. coli strains that contained either a multicopy $r n e^{+}$plasmid (pRNE101) or an otherwise identical plasmid lacking an $r n e$ insert (pACYCl77). The lac $Z^{-}$host strains for measuring expression of the $r n e-l a c Z$ fusion were $\mathrm{CH} 1827\left(\mathrm{rne}^{+}\right), \mathrm{CH} 1826$ (rne-3071), and CH1828 (ams-1) (Mudd et al. 1990). The host strain for measuring expression of the ompA-lacZ and IS10-lacZ fusions was CH1828. Each fusion was introduced in single copy by lysogeny of a $\lambda$ transducing phage. Wild-type lacZ expression was measured in HAK117 cells (ams-1 lacZ ${ }^{+}$) (Ono and Kuwano 1979) induced with IPTG (1 mM). Extracts were prepared from log-phase cultures grown at $37^{\circ} \mathrm{C}$ in minimal A medium (Miller 1972). At $30^{\circ} \mathrm{C}$, expression of the $r n e-1 a c Z$ fusion was 1.7 -fold higher in the rne-3071 strain and 4.4-fold higher in the ams-1 strain compared with the $m e^{+}$strain. Each value for $\beta$-galactosidase activity represents the average and standard deviation of three measurements.

${ }^{b}$ To calculate repression ratios, the $\beta$-galactosidase activity in cells containing pACYC177 was divided by the $\beta$-galactosidase activity in cells containing pRNE101. 
(Fig. 1). These mRNAs are barely detectable in RNA samples isolated from $r n e^{+}$cultures incubated at either $37^{\circ} \mathrm{C}$ or $42^{\circ} \mathrm{C}$. In contrast, strong bands of approximately equal intensity are apparent in lanes containing RNA isolated from the temperature-sensitive rne-3071 and ams-1 strains incubated at $42^{\circ} \mathrm{C}$. In cultures grown at $37^{\circ} \mathrm{C}$, the two mutant me alleles display dissimilar effects: The rne-3071 mutant behaves like the wild-type strain, whereas the ams-1 mutation, which has a more severe phenotype, causes elevated transcript levels similar to those observed with the same mutation at $42^{\circ} \mathrm{C}$. The differential effect of the two mutant rne alleles at $37^{\circ} \mathrm{C}$ parallels their effect on $\beta$-galactosidase production from the rne-lacZ fusion (Table 1). An advantage of analyzing the $a m s-1$ strain at $37^{\circ} \mathrm{C}$ is that a marked reduction in RNase E activity can be achieved without significantly impairing bacterial growth, thereby allowing the effects of this mutation to be evaluated under physiologically defined conditions. In contrast, growth of ams-1 and rne-3071 cells ceases after a temperature shift to $42^{\circ} \mathrm{C}$; consequently, the effects of RNase $\mathrm{E}$ inactivation may be difficult to distinguish from the effects of growth arrest at this temperature.

These findings indicate that $\mathrm{RNase} \mathrm{E}$ regulates its own synthesis by modulating the cellular concentration of the rne transcript. Furthermore, the similar response of rne mRNA and the hybrid rne-lacZ transcript to changes in cellular RNase $E$ activity implies that the regulation of the rne-lac $Z$ fusion by RNase E accurately mimics autoregulation of the rne gene and that the rne gene fragment present in the fusion contains all of the cis-acting signals necessary to mediate this phenomenon.

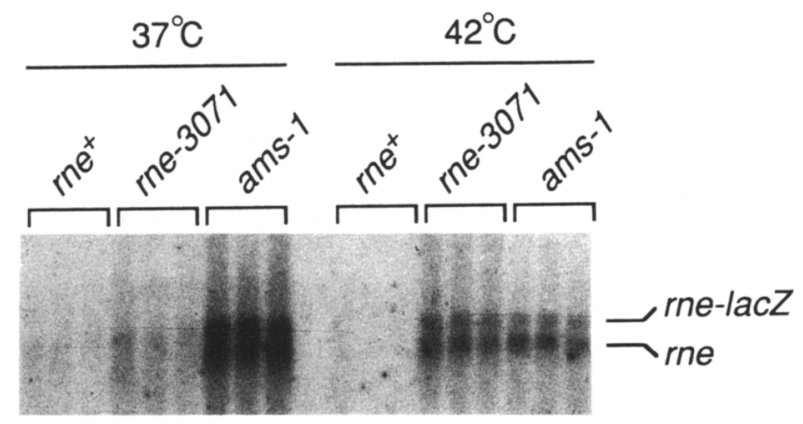

Figure 1. Northern blot analysis of rne and rne-lacZ transcripts in E. coli strains with various rne alleles. Total cellular RNA was isolated in triplicate from strains CJ1827 (mne $\left.{ }^{+}\right)$, CJ1826 (rne-3071), and CJ1828 (ams-1) that had been grown overnight at $30^{\circ} \mathrm{C}$, subcultured into fresh medium at $37^{\circ} \mathrm{C}$ for 1 $\mathrm{hr}$, and incubated for an additional hour at $37^{\circ} \mathrm{C}$ or $42^{\circ} \mathrm{C}$ prior to extracting RNA. The RNA samples $(10 \mu \mathrm{g})$ were fractionated by electrophoresis on a $1 \%$ agarose $/ 0.22 \mathrm{M}$ formaldehyde gel, blotted onto a nylon membrane, and probed with radiolabeled rne DNA. On the basis of their migration relative to rRNA and RNA molecular mass standards, the sizes of the hybridizing RNAs are close to the expected sizes of the me and me-lacZ transcripts (3.6 and $4.0 \mathrm{~kb}$, respectively) (Claverie-Martin et al. 1991; Casarégola et al. 1992; Yarchuk et al. 1992).

\section{Autoregulation does not involve changes in transcription}

In principle, feedback regulation of the cellular concentration of the rne transcript could be achieved by modulating either the transcription of the me gene or the decay of the rne transcript. To distinguish these two possibilities, we first inserted an inducible lac promoter $\left(\mathrm{P}_{\text {Iac }}\right) 0.2 \mathrm{~kb}$ upstream of an rne gene fragment that contains the promoter $\left(\mathrm{P}_{\text {rne }}\right), 5^{\prime} \mathrm{UTR}$, and the first 181 codons of the rne gene. The resulting plasmid, pLAC$\mathrm{RNE}^{\prime}$, was cotransformed into isogenic $r n e^{+}$and $a m s-1$ E. coli cells along with a compatible $l a c I^{\mathrm{q}}$ plasmid to repress $P_{l a c}$ transcription. RNA was isolated from these strains in the presence or absence of the $\mathrm{P}_{l a c}$ inducer IPTG, and these RNA samples were subjected to primer extension analysis using a 5 '-end-labeled oligonucleotide complementary to the rne transcript.

Major primer extension products of the sizes predicted for the $\mathrm{P}_{l a c}$ and $\mathrm{P}_{\text {rne }}$ transcripts were observed (Fig. 2). As expected, the abundance of the $P_{l a c}$ transcript increases upon addition of IPTG, whereas the $\mathrm{P}_{\text {rne }}$ transcript is not affected by this inducer. Furthermore, the concentrations of the $\mathrm{P}_{\text {lac }}$ transcript and the $\mathrm{P}_{\text {rne }}$ transcript both increase about fourfold in the ams-1 strain. This increase in $\mathrm{P}_{l a c}$ transcript concentration would not be expected if rne autoregulation occurred at the level of transcription, as transcription from the lac promoter normally is unresponsive to RNase E overproduction (Table 1) and as the lac promoter is located so far upstream from $\mathrm{P}_{r n e}$ that it is unlikely that any cis-acting $P_{r n e}$ element would influence transcription from $\mathrm{P}_{l a c}$. Instead, it seems likely that both the $\mathrm{P}_{l a c}$ and $\mathrm{P}_{m e}$ transcripts share within their common transcribed region an me mRNA determinant that mediates RNase E-dependent mRNA degradation and feedback regulation of rne gene expression.

Interestingly, we also observed a prominent primer extension product $\sim 50$ nucleotides shorter than that derived from the $\mathrm{P}_{r n e}$ transcript. A similar truncated RNA is detected when rne or rne-lacZ mRNA is analyzed using an RNase or S1 protection assay (see below) (Claverie-Martin et al. 1991). As the abundance of the truncated RNA is increased by IPTG induction of transcription from the upstream lac promoter, we conclude that this RNA species must arise by ribonuclease cleavage of the $\mathrm{P}_{1 a c}$ and $\mathrm{P}_{r n e}$ transcripts at a site within the rne 5' UTR and that it is not a direct product of transcription from a hypothetical promoter downstream of $\mathrm{P}_{r n e}$.

\section{The stability of the rne transcript is affected by RNase E activity in E. coli}

The arguments presented above suggest that the likely mechanism of rne autoregulation involves RNase E-mediated modulation of rne mRNA stability. To test this possibility directly, the half-life of the rne transcript was compared in three isogenic strains that contain different levels of RNase E activity. These strains have either an ams-1 mutation (low RNase E activity), a wild-type rne gene (normal RNase E activity), or a chromosomal $m e^{+}$ 


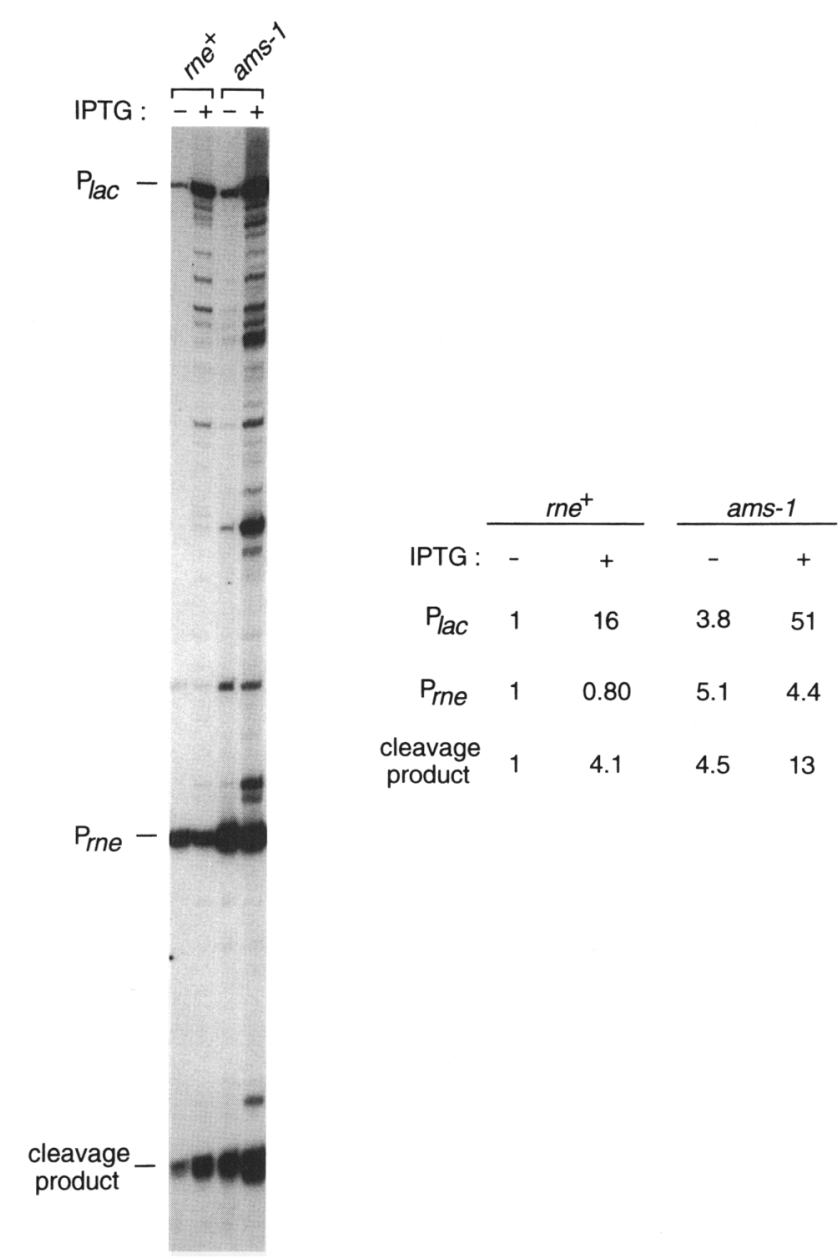

Figure 2. Primer extension comparison of hybrid me mRNAs transcribed from the rne promoter and an upstream lac promoter. Plasmid pLAC-RNE' was transformed into $E$. coli strains $\mathrm{CH} 1827\left(m e^{+}\right.$) and $\mathrm{CH} 1828$ (ams-1) containing the F-derived $1 a c I^{\mathrm{q}}$ plasmid $\mathrm{pRJM} 386$. Transformants were grown overnight at $30^{\circ} \mathrm{C}$ and subcultured for $45 \mathrm{~min}$ in prewarmed medium at $37^{\circ} \mathrm{C}$ in duplicate. IPTG (1 mM) was added to one of each duplicate culture to induce transcription from the lac promoter, and total cellular RNA was harvested 45 min later. Equal amounts of each RNA sample (5 $\mu \mathrm{g}$ ) were analyzed by primer extension with a $5^{\prime}$-end-labeled oligonucleotide $\left(5^{\prime}\right.$-TAACTGCCTGAAAGATCA-3') complementary to the plasmid-encoded transcripts. The primer extension products were fractionated by electrophoresis on a $4 \%$ acrylamide $/ 8 \mathrm{M}$ urea sequencing gel beside radiolabeled $\phi \mathrm{X174/HaeIII} \mathrm{markers} \mathrm{(not} \mathrm{shown).}$ Bands corresponding to rne mRNAs initiated at the $\mathrm{P}_{l a c}$ and $\mathrm{P}_{\text {me }}$ promoters are indicated, as is a band that corresponds to a major cleavage product of me mRNA. Relative to the $\phi \mathrm{X} 174 /$ HaeIII markers, the $\mathrm{P}_{l a c}$ and $\mathrm{P}_{\text {rne }}$ primer extension products migrate as expected based on their calculated lengths. Several additional bands of intermediate mobility are also visible, which presumably result either from cleavage of the $\mathrm{P}_{1 a c}$-derived rne transcript in vivo or from premature termination by reverse transcriptase. The data at right were obtained by integrating the intensity of the bands corresponding to the $\mathrm{P}_{l a c}$ and $\mathrm{P}_{\text {rne }}$ transcripts and the major cleavage product and normalizing each to its value in the sample from uninduced $m e^{+}$cells. gene plus the multicopy rne plasmid pRNE101 (high RNase E activity). Each of these strains also contains a chromosomal rne-lacZ fusion. To allow the rne transcript to be detected in cells with a high level of RNase E activity, a sensitive RNase protection assay was used. Total cellular RNA was isolated from each of the three strains at time intervals after transcription inhibition with rifampicin, annealed with a mixture of two radiolabeled RNA probes complementary to the $5^{\prime}$ and $3^{\prime}$ regions of the rne transcript, and treated with RNase T1. The protected probe fragments were then fractionated by electrophoresis on a nondenaturing polyacrylamide gel and detected by autoradiography (Fig. 3).

Five RNase-resistant products were observed: 1.26and $0.55-\mathrm{kb}$ fragments corresponding, respectively, to the $5^{\prime}$ and $3^{\prime}$ segments of the rne transcript, a $1.21-\mathrm{kb}$ fragment corresponding to a cleavage product of the rne transcript (see below), a $0.91-\mathrm{kb}$ fragment corresponding to the $5^{\prime}$ segment of the rne-lac $Z$ transcript, and a $0.86-$ $\mathrm{kb}$ fragment corresponding to an $\mathrm{rne}-\mathrm{lac} Z$ cleavage product. Quantification of the rate of disappearance of each band allowed the half-lives of the various mRNA segments to be calculated (Table 2). In addition, the half-life of the entire me transcript in the wild-type and ams-1 strains was measured using a long RNA probe complementary to virtually the whole $3.6-\mathrm{kb}$ transcript (Table 2). The half-life of the entire rne transcript in cells containing pRNE101 could not be determined (see below).

In each of the three strains, the half-lives of the $5^{\prime}$ and $3^{\prime}$ rne mRNA segments are similar to one another and to the half-life of the $5^{\prime}$ segment of the $r n e-l a c Z$ transcript: $\sim 9 \mathrm{~min}$ in the ams-1 strain, $1 \mathrm{~min}$ in the wild-type strain, and $0.6 \mathrm{~min}$ in the overproducing strain containing pRNE101. Moreover, in the wild-type and ams-1 strains, these half-lives are also similar to that measured for the entire rne transcript. Clearly, the longevity of the rne transcript is dependent on the level of RNase E activity in these cells. The simplest interpretation of this observation is that it reflects a modulation of the rate of RNase E-mediated cleavage of the rne transcript, though an indirect mechanism for the observed changes in rne mRNA stability cannot be excluded. In any event, these findings indicate that RNase E regulates its own synthesis by controlling the decay rate of the rne transcript.

\section{Feedback repression of RNase E synthesis}

The finding that the stability of the rne transcript and the expression of an rne-lacZ fusion are dependent on the level of RNase $E$ activity in $E$. coli suggests that RNase E production should be autoregulated. To test directly whether RNase E represses its own synthesis, we compared the cellular concentration of RNase $E$ in three isogenic strains that contain different levels of RNase $\mathrm{E}$ activity: an ams-1 strain (low RNase E activity), an $r n e^{+}$ strain (normal activity), and an $r n e^{+}$strain containing a plasmid (pRNE102) that encodes an active RNase E variant with a carboxy-terminal deletion (high activity). Each of these strains also contains a chromosomal rne- 
Figure 3. Determination of me and $r n e-l a c Z$ transcript half-lives in $E$. coli strains with various rne alleles and rne copy numbers. Cultures of CJ1828 (ams-1), CJ1827 (met), or CJ1827 containing plasmid pRNE101 (multicopy $r n e^{+}$) were grown to $\log$ phase at $37^{\circ} \mathrm{C}$ and treated with rifampicin to inhibit transcription. Total cellular RNA was isolated at time intervals thereafter. Equal amounts of each RNA sample $(5 \mu \mathrm{g})$ were analyzed by ribonuclease protection using a mixture of two radiolabeled RNA probes complementary to nucleotides 1-1257 and 2890-3466 of the $r n e$ transcript. The resulting RNase-resistant duplexes were electrophoresed on a nondenaturing $4 \%$ polyacrylamide gel beside radiolabeled $\phi X 174 /$ HaeIII DNA markers (not shown; see calibration). Bands corresponding to $5^{\prime}$ and $3^{\prime}$ segments of the rne transcript $(1.26$ and $0.58 \mathrm{~kb}$, respectively) and to a 5 ' segment of the rne-lacZ transcript ez1 $(0.91 \mathrm{~kb})$ are indicated. Just beneath the $5^{\prime}$ rne and $r n e-1 a c Z$ bands are two additional bands $(1.21$ and $0.86 \mathrm{~kb}$, respectively $)$ representing products of cleavage within the identical 5' UTRs of these two mRNAs. The ribonuclease-resistant RNA duplexes migrate somewhat more slowly than DNA duplexes of the same length.

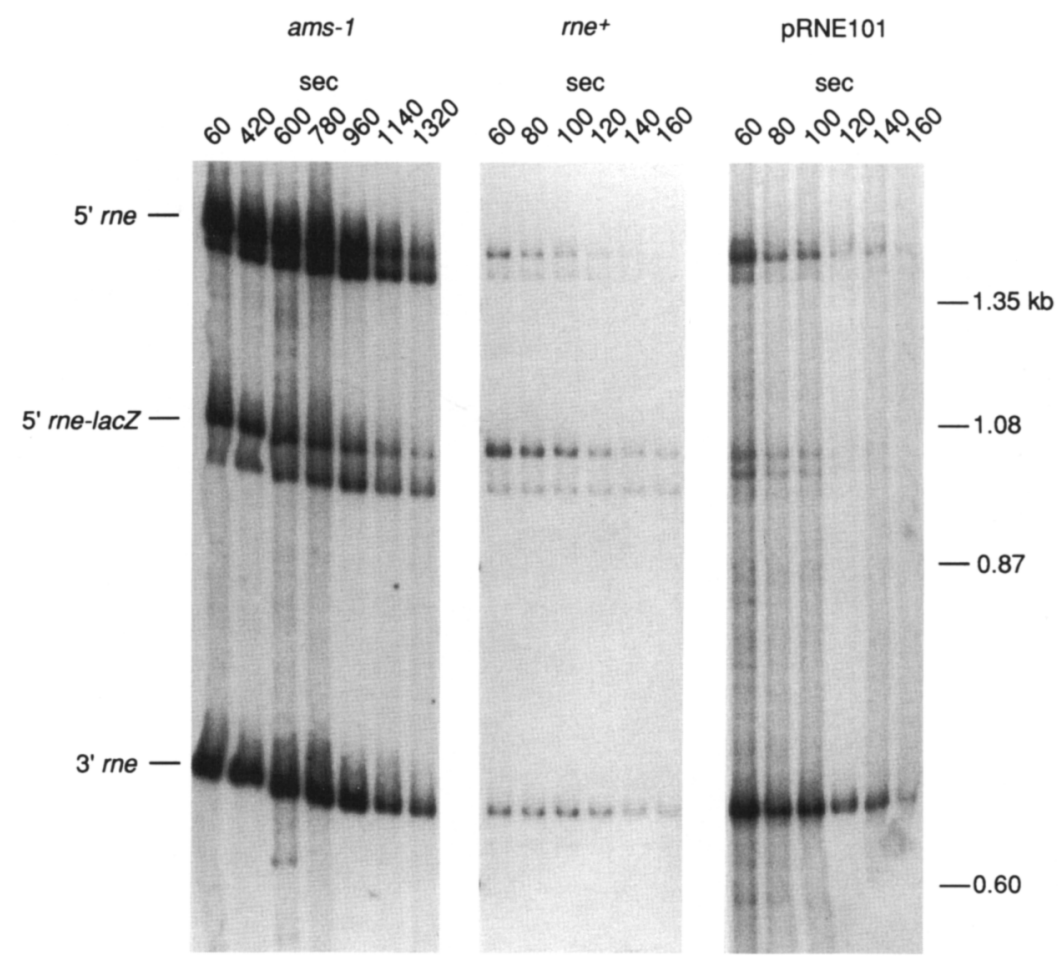

lacZ fusion, which serves as an independent reporter of feedback regulation.

Protein extracts prepared from each strain were fractionated by SDS-PAGE and analyzed by Western blotting

Table 2. Effect of cellular RNase E activity on rne and rne-lacZ $m R N A$ stability

\begin{tabular}{|c|c|c|c|c|}
\hline \multirow{3}{*}{$\begin{array}{l}\text { rne } \\
\text { genotype }\end{array}$} & \multicolumn{4}{|c|}{ Half-life $(\min )^{a}$} \\
\hline & \multicolumn{3}{|c|}{ rne } & \multirow{2}{*}{$\begin{array}{l}\text { rne-lacZ } \\
\left(5^{\prime} \text { segment }\right)\end{array}$} \\
\hline & full-length & 5' segment & $3^{\prime}$ segment & \\
\hline$a m s-1$ & 9.0 & 7.6 & 9.6 & 6.7 \\
\hline$m e^{+}$ & 1.0 & 0.8 & 1.3 & 1.0 \\
\hline pRNE101 & - & 0.6 & 0.7 & 0.6 \\
\hline
\end{tabular}

${ }^{a}$ E. coli strains CJ1828 (ams-1), CJ1827 (rne $e^{+}$, and CJ1827 containing plasmid pRNE101 (multicopy $\mathrm{rne}^{+}$) were grown to log phase at $37^{\circ} \mathrm{C}$. Transcription was inhibited with rifampicin, and total cellular RNA was isolated at time intervals thereafter. Equal amounts of each RNA sample were analyzed by RNase protection either with a probe complementary to virtually the entire rne transcript (full-length) or with a pair of probes complementary to the $5^{\prime}$ and $3^{\prime}$ segments of $m e$ mRNA (see Fig. 3). Besides revealing the half-life of rne mRNA and segments thereof, these experiments also provided information about the decay rate of the $5^{\prime}$-terminal $0.91-\mathrm{kb}$ segment of the rne-lacZ transcript $e z 1$, which is complementary to the full-length and 5' rne probes. The half-life of full-length me mRNA in CI1827 containing pRNE101 could not be measured because its concentration in these cells is below detectable levels. Each halflife value represents the average of two to four independent decay rate measurements. using antibodies raised against purified RNase E (Fig. 4). The yield of the chromosomally encoded RNase E protein was found to vary inversely with cellular RNase E activity. Compared with wild-type cells, the concentration of full-length RNase E increases fivefold in ams-1 cells and falls by almost a factor of 7 in wild-type cells containing pRNE102. The increased RNase E production in ams-1 cells versus $r n e^{+}$cells is accompanied by a similar increase in $\beta$-galactosidase synthesis from the resident rne-lacZ fusion (Fig. 4). Despite the greater concentration of RNase E in the ams-1 strain, the low specific activity of the thermolabile enzyme encoded by the ams-1 allele results in a net reduction in RNase E activity in these cells, as reflected by the increased stability of the rne transcript and the enhanced expression of the rne-lacZ fusion.

To assess how tightly the rne gene is autoregulated, we then quantitated the effectiveness of this feedback regulatory mechanism in compensating for an increased rne gene dosage. An $\mathrm{me}^{+}$E. coli strain containing a chromosomal rne-lacZ fusion was transformed with either of two multicopy plasmids bearing the wild-type rne gene: pRNE101, a derivative of pACYC177 that contains a p15A replication origin, and pRNE201, which contains a pSC101 replication origin. Western blot analysis of protein extracts showed that despite the increased rne gene dosage, the RNase E protein concentration in these cells is only two- to threefold higher than in the same cells lacking a plasmid (Fig. 4).

To quantify the increased rne gene dosage in cells containing pRNE101, the same host strain was transformed with plasmid pRNE/EZ101, which contains both an rne 


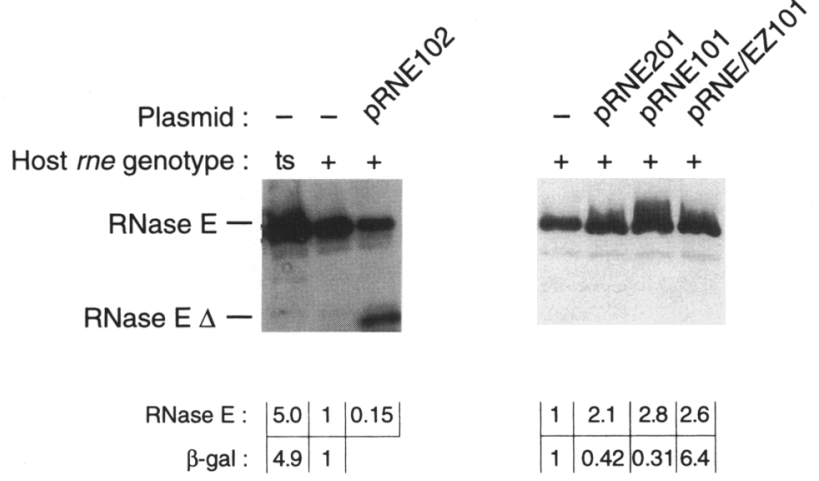

Figure 4. Comparison of RNase E protein levels in E. coli strains with various me alleles and $m e$ copy numbers. (Left) Protein extracts were prepared from log-phase cultures of three E. coli strains growing at $37^{\circ} \mathrm{C}$ : CJ1828 (ams-1), CJ1827 (me ${ }^{+}$), and CJ1827 containing plasmid pRNE102, which encodes a truncated but active form of RNase E. (Right) Protein extracts were prepared from log-phase cultures of strain CJ1827 $\left(r n e^{+}\right)$ containing plasmid pACYC177, pRNE201, pRNE101, or pRNE/ EZ101 and growing at $37^{\circ} \mathrm{C}$. Equal amounts of each protein sample $(5 \mu \mathrm{g})$ were analyzed by Western blotting, using antiRNase $E$ antibodies and enhanced chemiluminescent detection. The full-length RNase $\mathrm{E}$ protein $(118 \mathrm{kD})$ and the truncated RNase E variant encoded by pRNE102 (RNase E $\Delta, 90 \mathrm{kD}$ ) migrate anomalously with apparent molecular masses of 180 and $110 \mathrm{kD}$, respectively (Claverie-Martin et al. 1989; Casarégola et al. 1992). Beneath each lane is listed the relative abundance of the full-length RNase E protein, as determined by densitometry, and the relative amount of $m e-l a c Z$-derived $\beta$-galactosidase activity present in each strain.

gene and an rne-lacZ gene fusion and which, like pRNE101, is a derivative of pACYC177. As expected, cells containing pRNE/EZ101 produce the same somewhat elevated amount of RNase E as cells containing pRNE101 (2.6- vs. 2.8-fold; Fig. 4). By comparing $\beta$-galactosidase production from the single, chromosomal copy of the rne-lacZ fusion in cells containing pRNE101 and from the multiple copies of this fusion in cells containing pRNE/EZ101 (Fig. 4), we were able to calculate that the effective copy number of these two plasmids is 20 . This effective copy number reflects both the physical copy number of these plasmids and any possible differences in rne promoter activity on the plasmid versus the $E$. coli chromosome, and it provides an estimate of the increased rate of rne gene transcription in cells containing pRNE101 or pRNE/EZ101. As a 21-fold increase in the effective rne gene copy number results in only an $\sim 2.7$-fold increase in the concentration of the RNase E protein, we calculate that the yield of RNase E per effective $r$ e gene copy is reduced by a factor of 8 in cells containing pRNE101 or pRNE/EZ101. These findings demonstrate that RNase $\mathrm{E}$ is subject to tight, if imperfect, autoregulation.

Increasing the rne gene dosage reduces the cellular concentration of full-length rne $m R N A$

To determine whether the level of autoregulated RNase
E production is correlated with the steady-state concentration of the full-length rne transcript, RNA from an ams-1 strain, an $r n e^{+}$strain, and an $r n e^{+}$strain containing plasmid pRNE101 was analyzed by RNase protection using a radiolabeled probe complementary to the entire rne transcript (Fig. 5). Consistent with the Northern blot shown in Figure 1, the concentration of full-length rne mRNA in wild-type cells is only $5-10 \%$ of that in ams-1 cells, which contain a thermolabile form of RNase E with reduced specific activity. Interestingly, no fulllength rne mRNA can be detected in cells that contain

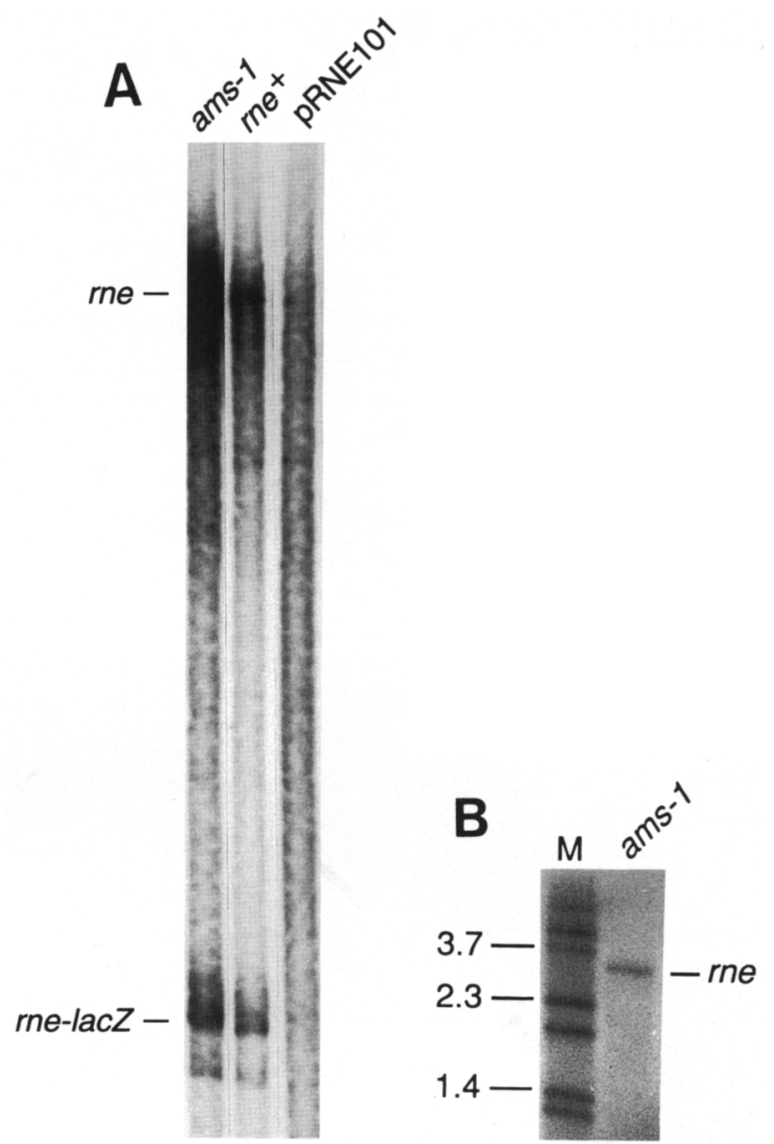

Figure 5. Steady-state levels of the full-length rne transcript in $E$. coli strains with various rne alleles and rne copy numbers. Total cellular RNA was isolated from log-phase cultures of three E. coli strains growing at $37^{\circ} \mathrm{C}$ : CJ1828 (ams-1), CJ1827 $\left(m e^{+}\right)$, or CJ1827 containing plasmid pRNE101 (multicopy $\left.r n e^{+}\right)$. Equal amounts of each RNA sample $(5 \mu \mathrm{g})$ were analyzed by ribonuclease protection using a single radiolabeled RNA probe complementary to virtually the entire me transcript (nucleotides 1-3466). (A) The resulting RNase-resistant duplexes were electrophoresed on a nondenaturing $4 \%$ polyacrylamide gel. Bands corresponding to the full-length rne transcript $3.47-$ $\mathrm{kb}$ RNase-resistant duplex) and to a 5' segment of the rne-lacZ transcript $e z 1(0.91 \mathrm{~kb})$ are indicated. $(B)$ To confirm the size of the RNase-resistant duplex formed when me mRNA is analyzed in this manner, a sample obtained by probing RNA from C) 1828 was also electrophoresed on a nondenaturing $0.7 \%$ agarose gel beside radiolabeled $\lambda / B s t$ EII markers. 
plasmid pRNE101. This latter observation is surprising for two reasons. First, in cells containing this plasmid, short segments of the rne transcript are up to 10-fold more abundant than in $r n e^{+}$cells lacking the plasmid (see Fig. 3; C. Jain and J.G. Belasco, unpubl.), as expected given that the presence of pRNE101 raises the rne gene dosage significantly more than it reduces the half-life of the $5^{\prime}$ and $3^{\prime}$ segments of the rne transcript. Second, cells containing pRNE101 produce more RNase E protein than their plasmid-free counterparts (Fig. 4).

A model to account for these paradoxical findings is presented in detail in the Discussion. According to this model, rne mRNA is so long $(3.6 \mathrm{~kb})$ and so short-lived that few nascent rne transcripts survive intact until their synthesis is completed. As a consequence, full-length rne mRNA fails to accumulate to a detectable level in cells that overproduce RNase E. A prediction of this hypothesis is that the steady-state concentration of a truncated rne transcript with a reduced synthesis time should be less sensitive to RNase E overproduction. To test this hypothesis, a $2.6-\mathrm{kb}$ segment was deleted inframe from the coding region of a plasmid-borne rne gene, and the effect of RNase E overproduction on the concentration and half-life of the resulting truncated transcript (rne302) was determined. This deletion, which leaves the 5 '-terminal $0.76-\mathrm{kb}$ rne mRNA segment intact, has no effect on mRNA half-life; in $r n e^{+}$cells and in cells that contain pRNE101, the $0.96-\mathrm{kb}$ rne302 message decays at essentially the same rate as the wild-type me transcript (Table 3). However, in contrast to its marked effect on wild-type rne mRNA, RNase E overproduction reduces the steady-state concentration of the truncated rne302 message only modestly. Whereas the abundance of full-length rne mRNA per me gene copy decreases by more than a factor of 40 when pRNE101 is introduced into $r n e^{+}$cells, the concentration of fulllength rne 302 mRNA declines by only a factor of $5(\mathrm{Ta}-$ ble 3). These findings support the conclusion that the brevity of the rne mRNA half-life compared with its expected synthesis time makes the steady-state concentration of the wild-type message extremely sensitive to changes in its stability.

\section{Cis-acting rne elements necessary for feedback regulation}

To delimit further the region of the rne transcript necessary in cis for feedback regulation by RNase E, we analyzed the effect of deletions in the rne segment of the aforementioned rne-lacZ fusion (ez1), which comprises the promoter, $5^{\prime}$ UTR, and first 181 codons of the rne gene fused in-frame to the tenth codon of lacZ. These constructs were introduced into an ams-1 E. coli strain with low RNase $\mathrm{E}$ activity either by integration into the chromosome or by transformation as part of a low-copynumber plasmid. $\beta$-Galactosidase production was then assayed in the presence and absence of RNase E overproduction from plasmid pRNE101 (Table 4).

Overproduction of RNase E reduces expression of the $e z 1$ fusion in these cells by a factor of $\sim 35$ regardless of
Table 3. Effect of mRNA truncation on the concentration and half-life of rne mRNA in $\mathrm{rne}^{+}$and pRNE101 strains

\begin{tabular}{|c|c|c|c|c|}
\hline \multirow[b]{2}{*}{ Transcript $^{\mathbf{a}}$} & \multicolumn{2}{|c|}{ Half-life (min) } & \multirow[b]{2}{*}{$\begin{array}{l}\text { Half-life } \\
\text { ratio }^{\text {b }}\end{array}$} & \multirow{2}{*}{ 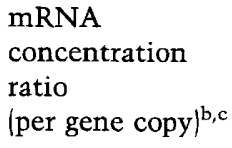 } \\
\hline & $\begin{array}{l}r n e^{+} \\
\text {strain }\end{array}$ & $\begin{array}{l}\text { pRNE101 } \\
\text { strain }\end{array}$ & & \\
\hline rne & 1.0 & $0.65^{d}$ & 1.5 & $>40^{d}$ \\
\hline me302 & 1.1 & 0.8 & 1.4 & 4.7 \\
\hline
\end{tabular}

${ }^{a}$ Half-life values and relative steady-state concentrations of the full-length rne transcript were determined in CJ1827 containing either pACYCl 77 ( $m e^{+}$strain) or pRNE 101. Corresponding values for full-length rne302 mRNA were determined after introducing plasmid pRNE302 into the same two strains. In these assays, mRNA from exponentially growing cultures was detected by RNase protection using a radiolabeled probe complementary to virtually the entire rne transcript or to the entire me302 transcript. Data for $m e$ mRNA are derived from Table 2 and Fig. 5. The rne302 transcript is an in-frame fusion of the 5 '-terminal $0.76-\mathrm{kb}$ segment and 3 '-terminal $0.20-\mathrm{kb}$ segment of rne mRNA.

${ }^{\text {b}}$ Ratios represent the value in the $r n e^{+}$strain divided by the value in the pRNE101 strain.

'The relative concentrations of the rne and $m e 302$ transcripts in the $r n e^{+}$and pRNE101 strains were determined by RNase protection analysis of equal amounts of total cellular RNA and normalized to the effective rne or rne302 gene copy number in each strain. The effective $r n e$ gene copy number is 1 in the $r n e^{+}$ strain and 21 in the pRNE101-containing strain (see text), whereas the corresponding values for the rne302 gene encoded by pRNE302 (a pBR322-based plasmid) are 19 and 26, respectively. These values for the effective copy number of pRNE302 in the $m e^{+}$and pRNE101 strains were estimated by measuring the copy number of another pBR322 derivative, pEZ301, in these strains. This latter plasmid contains a copy of the rnelac $Z$ fusion $e z 1$, and by comparing the level of $\beta$-galactosidase activity produced from a single-copy $e z 1$ fusion on the chromosome vs. a multicopy ez1 fusion on pEZ301, we determined in each strain the effective copy number of pEZ301 and, by implication, pRNE302.

${ }^{\mathrm{d}}$ Because full-length rne transcripts could not be detected in cells containing pRNE101, the half-life listed in this case is the average value determined for $5^{\prime}$ and $3^{\prime}$ segments of the transcript (see Table 2), and a lower limit is indicated for the concentration ratio of $m e$ mRNA in the $r n e^{+}$and pRNE101 strains.

whether the gene fusion is present on the chromosome or on a plasmid. A similar repression ratio is observed when rne codons $29-181$ are deleted (ez2), demonstrating that the $5^{\prime}$ UTR and first 28 codons of rne are sufficient to mediate efficient feedback repression by RNase E. This finding explains why rne 302 mRNA decays with the same kinetics as the wild-type rne transcript (see above), as rne 302 retains the $5^{\prime}$ UTR and first 134 codons of rne. In contrast, a deletion that removes all but the last 24 nucleotides of the 361-nucleotide rne-lacZ $5^{\prime}$ UTR and leaves the ribosome-binding site intact completely abolishes the responsiveness of the gene fusion to RNase E activity (ez6). Smaller deletions that remove internal segments (67 or 188 nucleotides) of the ez1 $5^{\prime}$ UTR have an intermediate effect, reducing the repres- 
Table 4. Deletion mapping of cis-acting rne elements important for feedback regulation by RNase E

\begin{tabular}{lll}
\hline & $\beta$-Galactosidase (units) & $\begin{array}{l}\text { Repression } \\
\text { ratio }\end{array}$ \\
\hline
\end{tabular}

Single-copy fusions

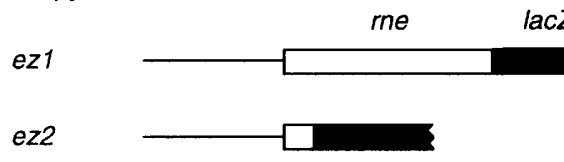

$\begin{array}{lll}1160 & 36 & 32 \\ 2460 & 63 & 39\end{array}$

Plasmid-borne fusions

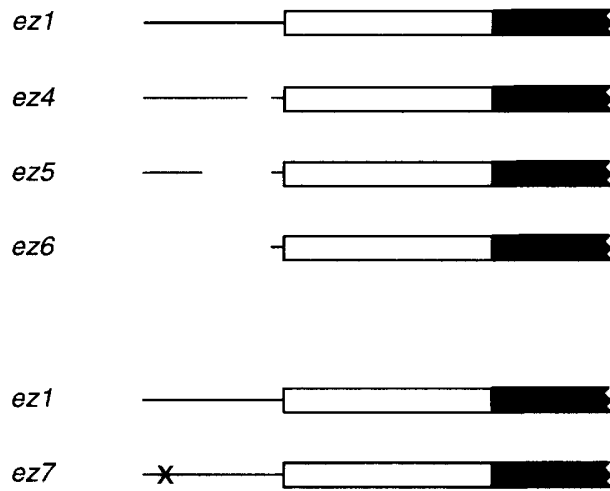

$\begin{array}{lll}4930 & 134 & 37 \\ 600 & 112 & 5.4 \\ 2960 & 635 & 4.7 \\ 1370 & 1550 & 0.9 \\ 3660 & 98 & 37 \\ 2690 & 84 & 32\end{array}$

\begin{abstract}
${ }^{2}$ All $\beta$-galactosidase assays were performed on extracts of an ams-1 lac $Z^{-}$E. coli strain $(\mathrm{CH} 1828)$ containing both an rne-lac $Z$ fusion and either a multicopy $m e^{+}$plasmid (pRNE101) or a control plasmid (pLG339). The various rne-lacZ fusions were introduced either in single copy by lysogeny of a transducing phage or in multiple copies via a pSC101-derived plasmid vector. Cells were grown at $37^{\circ} \mathrm{C}$ in minimal A medium. For each of the two sets of assays with plasmid-borne rne-lacZ fusions $(e z 1, e z 4, e z 5, e z 6$, and $e z 1, e z 7)$, a separate measurement of $\beta$-galactosidase activity was performed with control cells that produce $e z 1$ mRNA to provide a same-day value for comparison of repression ratios. The 5 ' segment of each rne-lacZ hybrid transcript is represented diagramatically. (Lines) me $5^{\prime}$ UTR; (口) 5'-terminal segment of the rne protein-coding region; ( $\square$ ) 5' portion of the lacZ protein-coding region; (gaps) deleted rne $5^{\prime}$ UTR segment; (X) 5-nucleotide substitution (AUUUU $\rightarrow$ GGGGG) at a major cleavage site within the $r n e 5^{\prime}$ UTR. The central and $3^{\prime}$-terminal segments of these transcripts are not shown.
\end{abstract}

sion ratio to $5(e z 4, e z 5)$. These findings show that the rne 5' UTR is essential for RNase E-mediated down-regulation.

In $E$. coli, the rne and $e z 1$ transcripts are both cleaved within the $5^{\prime}$ UTR at a site near the $5^{\prime}$ end (Figs. 2 and 3). As this site lies within a $5^{\prime}$ UTR segment that is important for feedback regulation by RNase E (Table 4), we decided to investigate whether cleavage there is a key step in this regulatory process. We first mapped the cleavage site at high resolution by using primer extension analysis to identify the $5^{\prime}$ end of this ez1 mRNA cleavage product and of the full-length ez1 transcript. Cleavage was found to occur at a site 48 nucleotides downstream of the $5^{\prime}$ terminus of the intact transcript (Fig. 6A). Interestingly, the AU-rich sequence immediately downstream of this cleavage site (AUUUU) resembles the corresponding sequence of several known RNase E cleavage sites (Ehretsmann et al. 1992) and may contribute to recognition by this ribonuclease. We then converted these five nucleotides to guanosine nucleotides (ez7). This mutation abolishes cleavage at the normal site but allows cleavage to occur with reduced efficiency at new sites (Fig. 6B). Despite creating an impediment to cleavage, this mutation has little or no effect on repression of the rne-lacZ fusion by RNase E (Table 4) or on the steady-state concentration of the intact rne-lac $Z$ hybrid transcript in $r n e^{+}$cells. These findings indicate that cleavage of the rne-lacZ transcript at this site is not essential for the degradation of this mRNA or for feedback regulation by $\mathrm{RNase} \mathrm{E}$.

\section{The amino-terminal half of the RNase E protein is} sufficient to repress me gene expression

To identify the region of the 1061-amino-acid RNase E protein that causes repression of rne gene expression, carboxy-terminal deletions were created in the rne gene of plasmid pRNE101. The resulting deletion mutants were introduced by plasmid transformation into an ams-1 E. coli strain (CJ1828) containing a chromosomal rne-lacZ fusion (ez1), and the effect of each deletion on $\beta$-galactosidase production was determined in cells growing at $37^{\circ} \mathrm{C}$. In addition, we assessed the ability of each RNase $\mathrm{E}$ mutant to complement the temperature- 
A

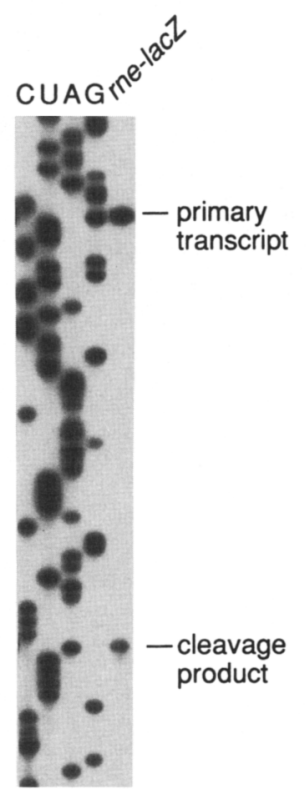

B

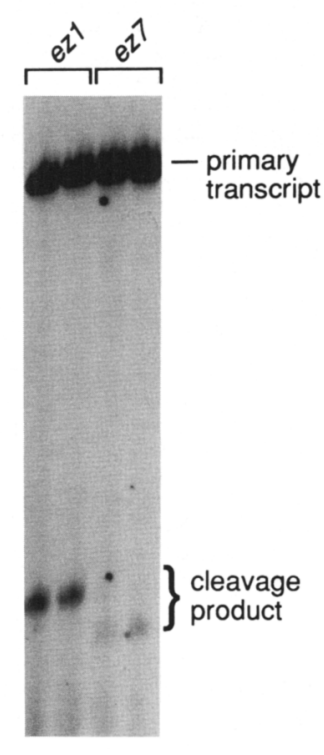

Figure 6. Effect of a cleavage site mutation on the concentration of an $r n e-l a c Z$ transcript and on its cleavage in $E$. coli. $(A)$ Mapping of the 5' ends of an $r n e-l a c Z$ transcript and its principal 5' UTR cleavage product. Total cellular RNA was isolated from a log-phase culture of $E$. coli strain MCl061 containing plasmid pEZ201, which encodes the rne-lac $Z$ hybrid transcript $e z 1$. The RNA was analyzed by primer extension with a 5 '-endlabeled oligonucleotide (5'-TAACTGCCTGAAAGATCA-3') complementary to an mRNA segment located 95-112 nucleotides from the $5^{\prime}$ end of the $m e-l a c Z$ transcript. The primer extension products were electrophoresed on a $4 \%$ polyacrylamide-urea gel beside a cognate sequencing ladder generated by primer extension on an rne DNA template. The sequencing lanes are labeled $(C, U, A, G)$ to indicate the sequence of the RNA transcript. Bands corresponding to the 5 ' ends of the rnelacZ transcript (5'-GUUUCCGUGU...) and its principal $5^{\prime}$-UTR cleavage product $\left(5^{\prime}\right.$-AUUUUGCCCG. . .) are marked. These ends map 2-3 nucleotides upsteam of the positions mapped previously for me mRNA by $\mathrm{S} 1$ protection analysis (Claverie-Martin et al. 1991). Because high-resolution S1 mapping can be impaired by breathing at the termini of DNA/RNA duplexes, we consider the primer extension data to be more reliable. $(B)$ Effect of a cleavage site mutation on rne-lac $Z$ mRNA cleavage and abundance. Total cellular RNA was isolated from duplicate log-phase cultures of $E$. coli strain MC1061 containing plasmid pEZ201 (ez1) or pEZ207 (ez7) and growing at $37^{\circ} \mathrm{C}$. Equal amounts of each RNA sample were analyzed by primer extension with the end-labeled oligonucleotide described above ( $5^{\prime}$-TAACTGCCTGAAAGATCA-3'). Bands corresponding to the $5^{\prime}$ ends of the $r n e-l a c Z$ transcript and its principal 5'-UTR cleavage product are marked. Together, the abundance of the multiple $e z 75^{\prime}$-UTR cleavage products is only $15-30 \%$ of the abundance of the $e z 1$ cleavage product, whereas the concentrations of the uncleaved $e z 1$ and $e z 7$ transcripts are the same. Because plasmid-encoded $r n e-l a c Z$ mRNA is about nine times more abundant than chromosomally encoded $r n e$ mRNA in these cells, the contribution of the latter to the observed primer extension products is negligible. sensitive growth defect caused by the ams-1 mutation at the nonpermissive temperature $\left(42^{\circ} \mathrm{C}\right)$.

Deletions that remove the carboxy-terminal 247, 408, or 563 amino acid residues of RNase E only partially impair its potency in feedback regulation, reducing the repression ratio from $\sim 30$ (full-length RNase E) to a factor of $6(\Delta 563)$ to $12(\Delta 247, \Delta 408)$, and all three of these mutants permit growth of the ams-1 strain at $42^{\circ} \mathrm{C}$. In contrast, deletion of 591 or 601 residues from the RNase E carboxyl terminus or of residues 29-314 near the amino terminus completely eliminates the ability of RNase $\mathrm{E}$ to repress rne-lacZ expression and to restore viability to the ams-1 strain at the nonpermissive temperature. These findings delimit the amino-terminal RNase E domain necessary for feedback regulation and cell viability and show that these two phenomena are correlated. The data also suggest that the carboxy-terminal region of RNase $\mathrm{E}$ has no intrinsic ability to repress rne gene expression.

\section{Discussion}

Our data show that RNase E tightly regulates its own synthesis by controlling the decay rate of the rne transcript. Thus, a 21-fold increase in the rate of rne transcription results in only a 2.7 -fold increase in RNase E production because of accelerated degradation of the rne transcript. Conversely, cells with diminished RNase E activity compensate by prolonging the lifetime of the rne transcript, thereby allowing as much as a fivefold increase in the rate of RNase E protein synthesis. By buffering the production of RNase $\mathrm{E}$, this autoregulation mechanism helps to protect $E$. coli cells from the debilitating effects of RNase E levels that are excessively high or low.

Feedback regulation is mediated in cis by the $5^{\prime}$-terminal 0.45 -kb rne mRNA segment, which can confer this property onto a heterologous mRNA to which it is fused. This segment comprises the 361-nucleotide rne 5' UTR, which is essential for feedback regulation, and the first 28 codons of the rne protein-coding region. Mutation of a major site of cleavage within the rne 5' UTR disrupts cleavage there but does not impair the ability of the $5^{\prime}$ UTR to respond to changes in cellular RNase E activity, even though the sequence surrounding this site resembles other known RNase E cleavage sites. Presumably, disruption of this site is inconsequential either because cleavage there is unrelated to feedback regulation and does not trigger further mRNA decay or because this is only one of several potential sites where RNase E can initiate the degradation of rne mRNA.

Like the intact RNase E protein, the amino-terminal half of RNase E can both repress rne gene expression and complement the growth defect caused by a chromosomal ams-1 mutation at $42^{\circ} \mathrm{C}$. These findings suggest that the active site of this ribonuclease lies within its aminoterminal region, the downstream boundary of which maps between amino acid residues 470 and 498 . Whether shorter amino-terminal RNase E fragments fail to repress me-lac $Z$ expression and complement the ams-1 
mutation because they lack sufficient ribonuclease activity or because they are labile in E. coli is not clear.

Paradoxically, increasing the rne gene copy number in $E$. coli results in a modest increase in RNase E protein synthesis despite an unexpected reduction in the concentration of the full-length rne transcript. Why should the abundance of $r n e$ mRNA decline despite a significant increase in the copy number of the rne gene, and how does the cell manage to produce more RNase $\mathrm{E}$ from less rne mRNA? The likely answer is that transcription, mRNA degradation, and translation can all occur simultaneously and that a substantial fraction of rne messages decay cotranscriptionally. On the basis of the average rate of transcript elongation by $E$. coli RNA polymerase [30-50 nucleotides/sec (Rose et al. 1970; Jin et al. 1992)], it should take $\sim 70-120 \mathrm{sec}$ to synthesize the $3.6-\mathrm{kb}$ rne transcript. As this synthesis time is longer than the brief half-life of $r n e$ mRNA in wild-type cells and in cells that overproduce RNase $\mathrm{E}$, most nascent rne transcripts in such cells should begin to decay before their synthesis is completed. Consequently, the longevity of rne mRNA will affect the steady-state concentration of the fulllength transcript not only by determining its rate of turnover once transcription has been completed but also by affecting the probability that nascent transcripts will remain undegraded until they reach full length. In general, for an mRNA with a half-life $|\tau|$ that is significantly shorter than its synthesis time $(t)$ and that does not change appreciably as the nascent transcript elongates, only a small fraction of transcripts $\left(2^{-t / \tau}\right)$ will survive intact until the time that their synthesis has been completed.

The substantially amplified impact of mRNA degradation under these circumstances would allow even a modest acceleration of $r n e$ mRNA decay to cause a marked reduction in the abundance of the full-length rne transcript per gene copy. In cells containing pRNE101, we calculate that this phenomenon could overwhelm the opposing effect of an increased rne gene dosage on the concentration of full-length rne mRNA if the half-life of the $3.6-\mathrm{kb}$ rne transcript is inversely proportional to the concentration of RNase E (i.e., $22 \mathrm{sec}$ in the presence of pRNE101) and if the average rate of elongation of this transcript is $\sim 25$ nucleotides/sec. In this regard, it is important to bear in mind that the measured half-lives of the $5^{\prime}$ - and $3^{\prime}$-terminal rne mRNA segments in cells containing pRNE101 $(\sim 40 \mathrm{sec})$ only set an upper limit on the half-life of the full-length rne transcript, which under these conditions is too labile to be detected and which in theory might decay at a rate as high as the sum of the decay rates of its component segments. The apparent susceptibility of the nascent rne transcript to rapid degradation and the resulting preponderance of nascent and partially degraded rne transcripts also help to explain why the component segments of rne mRNA can be detected in cells that contain pRNE101, whereas the fulllength $r n e$ transcript cannot (see Figs. 3 and 5).

To test the hypothesis that the sensitivity of rne mRNA to changes in its decay rate is in part a consequence of its relatively long synthesis time, we have ex- amined the effect of transcript length on this phenomenon. Consistent with our model, RNase E overproduction has a much smaller effect on the cellular concentration of the truncated rne302 message, which is just as labile as the wild-type transcript in cells containing normal and elevated levels of RNase E but only onefourth as long. The enhanced impact of mRNA decay on the cellular concentration of transcripts whose half-life is shorter than their synthesis time may have important implications for the expression of other long transcripts that are rapidly degraded in prokaryotic organisms (e.g., transcripts of polycistronic operons) or in eukaryotic cell nuclei.

As for the ability of cells containing pRNE101 to produce two- to threefold more RNase E despite a reduced abundance of the full-length rne transcript, this must surely be the result of translation of nascent and partially degraded rne transcripts, whose synthesis is initiated more frequently in cells with an increased rne gene dosage. Given the potential for translating ribosomes to complete the synthesis of nascent RNase E polypeptide chains despite the degradation of $r n e$ mRNA segments that lie upstream, it is not surprising that the concentration of full-length rne transcripts is not fully representative of the available mRNA template for RNase E synthesis.

Another unexpected feature of feedback regulation by RNase $E$ is its selective effect on gene expression. The rne, ompA, and IS10 transposase transcripts all decay more slowly when RNase E is completely inactivated at $42^{\circ} \mathrm{C}$ in an $r n e^{t s}$ E. coli strain (Lundberg et al. 1990; Mudd et al. 1990; Jain and Kleckner 1993); however, when these genes are fused in-frame to $1 a c Z$, expression of only the rne-lacZ fusion is sensitive to more modest changes in cellular RNase E activity. It seems unlikely that the differential response of these $l a c Z$ fusions can be explained by positing that the decay determinants of the parent mRNAs are absent from the ompA-lacZ and IS10-lac $Z$ hybrid transcripts, as the ompA-lac $Z$ transcript is known to share the decay characteristics and key decay determinants of $o m p A$ mRNA (Hansen et al. 1994). The unique behavior of the rne-lac $Z$ transcript also cannot be adequately explained by the brevity of its half-life compared with its synthesis time, as some reduction in expression would be expected even for a longlived transcript under conditions of accelerated mRNA decay. Instead, it seems more likely that the rate-determining event in the functional inactivation of the ompA-lacZ and IS10-lacZ transcripts via the RNase E degradation pathway is rather insensitive to the concentration of this enzyme. For example, mRNA degradation appears to be a multistep process (Belasco 1993), and for some mRNAs that are degraded via the RNase E pathway, cleavage by this enzyme might not be the ratelimiting step in translational inactivation except perhaps in the extreme circumstance of complete RNase $\mathrm{E}$ inactivation (e.g., ams-1 cells at $42^{\circ} \mathrm{C}$ ). Alternatively, whereas RNase E alone may be able to initiate the degradation of its own message, the efficient cleavage of other mRNAs by this ribonuclease may also require one 
or more auxiliary factors, which might be present in $E$. coli at a limiting concentration. If so, the excess of RNase E under normal conditions could explain why the expression of some lac $Z$ fusions is not affected by moderate changes in the cellular abundance of this protein.

Closer examination of RNase $E$ feedback regulation should provide valuable insights into the mechanism of action of this key ribonuclease and its selective effects on gene expression. In light of evidence that the RNase E pathway for mRNA degradation involves multiple steps and additional E. coli proteins (Belasco 1993; He et al. 1993; Xu et al. 1993; Carpousis et al. 1994), it will be important to identify and characterize the other cellular factors involved in this regulatory pathway. The marked sensitivity of $r n e-l a c Z$ expression to cellular RNase E activity suggests a genetic screening strategy for identifying $E$. coli gene products that influence mRNA degradation by RNase E.

\section{Materials and methods}

\section{Bacterial strains and plasmids}

The isogenic E. coli K-12 strains CH1826 (MC1061, zce726::Tn10 rne-3071), CH1827 (MC1061, zce-726::Tn10), and $\mathrm{CH} 1828$ (MC1061, zce-726::Tn10 ams-1) are all derivatives of MC1061 (araD39 $\Delta\left(\right.$ ara,leu)7697, LlacX74 $\mathrm{galU}^{-} \mathrm{galK}^{-} \mathrm{hsr}^{-}$ $\mathrm{hsm}^{+}$strA). These strains and HAK1 17 (thr leu pro argE rpsL gal ams-1 $\mathrm{Sm}^{\mathrm{r}}$ ) have been described previously (Ono and $\mathrm{Ku}-$ wano 1979; Mudd et al. 1990). Strains CJ1826, CJ1827, and $\mathrm{CJ} 1828$ were created by inserting an $m e-l a c Z$ fusion $(e z 1)$ into the chromosome of $\mathrm{CH} 1826, \mathrm{CH} 1827$, and $\mathrm{CH} 1828$, respectively (see below).

Chromosomally located $r n e-l a c Z$ and ompA-lacZ gene fusions were constructed in several steps. A plasmid-borne gene fusion (ez1) comprising the 5' UTR and first 181 codons of the E. coli rne gene joined in-frame to the tenth codon of $l a c Z$ was constructed by inserting a $1.0-\mathrm{kb} B c l \mathrm{I}-\mathrm{HindIII}$ fragment from pFMK32 (Claverie-Martin et al. 1989) between the BamHI and HindIII sites of pLACZY3 (Jain 1993) to generate pEZ101. Deletion of an EcoRV-HindIII fragment of pEZ10l comprising rne codons 29-181 generated plasmid pEZ102. To construct an ompA-lacZ plasmid, the $5^{\prime}$ UTR and first four codons of ompA were fused in-frame to $l a c Z$ by inserting a 650-bp EcoRI-NruI fragment derived from pOMPA100 (Chen et al. 1991) between the EcoRI and SmaI sites of pCJ249 (Jain 1993). These plasmidencoded gene fusions were recombined with $\lambda$ phage variant $\lambda$ RS45 (Simons et al. 1987) via homologous bla and lac flanking sequences. Recombinant phage, identified by their blue plaque phenotype, were then purified and allowed to lysogenize into the chromosome of various $E$. coli strains to yield single-copy gene fusions. An $E$. coli strain with a single-copy IS10-lac $Z$ fusion was similarly obtained by lysogeny of $\lambda$ NK1167, a $\lambda$ RS45 derivative containing an IS10-lacZ fusion and obtained from Nancy Kleckner (Harvard University, Cambridge, MA).

The plasmid-borne $r n e-l a c Z$ fusions used for deletion analysis of cis-acting RNA elements were first constructed in a pBR322-derived plasmid vector and then subcloned into a pSC101-derived plasmid vector. By oligonucleotide-directed mutagenesis, a unique StuI restriction site was created in the me-lacZ 5' UTR of pEZ101 by inserting 4 bp (GGCC) at a position $24 \mathrm{bp}$ upstream of the translation initiation codon. A 9.3-kb EcoRI-StuI fragment of the resulting plasmid was then ligated to each of three pEZ101 fragments, all of which contained the rne promoter. Ligation to a $0.42-\mathrm{kb} E c o \mathrm{RI}-B s t \mathrm{UI}$ fragment of pEZ101 created pEZ104, which encodes ez4. Ligation to a $0.30-\mathrm{kb}$ EcoRI-SspI fragment of pEZ101 created pEZ105, which encodes ez5. Ligation to a 0.14-kb EcoRI-HaeIII fragment of pEZ101 created pEZ106, which encodes ez6. To construct the low-copy-number $r$ e-lacZ fusion plasmids pEZ201, 204, 205, and 206, a 3.6- to 4.2-kb EcoRI-DraI fragment containing the rne-lacZ fusion was excised from plasmids pEZ101, pEZ104, pEZ105, and pEZ106, respectively, and inserted between the EcoRI and EcoRV sites of pWSK30, a pSC101-based cloning vector (Wang and Kushner 1991). Plasmid pEZ207, which encodes $e z 7$, was created by oligonucleotide-directed mutagenesis of pEZ201 to convert the sequence corresponding to an RNA cleavage site in the 5' UTR from ACCCATTTTGCCC to ACCCGGGGGGCCC.

Plasmid pRNE101 was constructed by digesting plasmid pSCl3 (Casarégola et al. 1992) with PstI and subcloning a 5.6-kb fragment that contains the entire E. coli rne gene into the PstI site of pACYC177 (Rose 1988a) such that transcription of the rne and bla genes was in opposite directions. The pSC101-based plasmid pFMK32, which also contains the entire rne gene, has been described previously (Claverie-Martin et al. 1989) and is referred to in Fig. 4 as pRNE201. Plasmid pRNE/EZ101 was constructed in multiple steps. First, a $1.1-\mathrm{kb}$ ScaI-BamHI fragment of Bluescript $\mathrm{KS}$ ( +) (Stratagene) was ligated to a 3.2-kb ScaI-BamHI fragment of pACYCl77 to generate a plasmid (pACYC/BS) encoding resistance to both ampicillin and kanamycin. Then, plasmid pRNE1 10 was constructed by inserting a 5.6-kb PstI fragment of pSC13 that contains the entire E. coli rne gene into the PstI site of $\mathrm{pACYC} / \mathrm{BS}$, such that transcription of the rne and bla genes was in the same direction. Finally, a 4.2-kb XbaI-DraI fragment containing the $r n e-l a c Z$ fusion $e z 1$ was ligated to an 8.4-kb XbaI-ScaI fragment of pRNE110 to generate pRNE/EZ101.

Plasmid derivatives of pRNE101 lacking portions of the me protein-coding region were constructed as follows. Plasmids pRNE102, pRNE103, and pRNE104, which encode RNase E variants lacking 247,408 , or 563 carboxy-terminal amino acid residues, respectively, were created by deleting a pRNE101 fragment extending from a $B a m H I$ site downstream of $r n e$ to a BamHI, MluI, or AfIII site within the RNase E-coding region. Plasmids pRNE105 and pRNE106, which encode RNase E variants lacking 591 or 601 carboxy-terminal amino acid residues, respectively, were constructed by cleaving pRNE101 with AfIII and treating the resulting linear DNA fragment with nuclease BAL 31. The DNA was then cleaved with BamHI, the ends were made blunt with T4 DNA polymerase, and the DNA was circularized with incorporation of an $\mathrm{XbaI}$ linker $\$ 5^{\prime}$-CTAGTCTAGACTAG-3'). The deletion endpoints of pRNE105 and pRNE106 were determined by DNA sequencing. Plasmid pRNE107 is an in-frame deletion mutant of pRNE101 lacking a $0.85-\mathrm{kb}$ EcoRV fragment that encodes RNase E amino acid residues 29-314.

Plasmid pRNE302 was constructed in two steps. First, the 5.6-kb Pst I fragment of pSC13 containing the entire rne gene was subcloned into the PstI site of pBR322 to give a plasmid (pRNE301) in which transcription of the rne and tet genes was in opposite directions. Deletion of a 2.6-kb BssHII fragment between rne codons 135 and 1013 then yielded pRNE302. Plasmid pEZ301, used to measure the copy number of pBR322-derived plasmids in $m e^{+}$and pRNE101-containing strains, was also constructed in two steps. First, a $1.4-\mathrm{kb}$ SnaBI-NarI fragment of pEZ101 was replaced with a polylinker sequence containing a PstI site and derived from pOK12/Vieira and Messing 1991). A 5.0-kb EcoRI-PstI fragment containing the rne-lacZ 
fusion was then excised from the resulting plasmid and inserted between the EcoRI and PstI sites of pBR322 to yield pEZ301.

Plasmid pLAC-RNE' was constructed by inserting the $1.0-\mathrm{kb}$ BclI-HindIII rne fragment of pFMK32 between the BamHI and HindIII sites of plasmid Bluescript SK| + (Stratagene). Plasmids pT7rneFL and pT7rne $5^{\prime}$ are templates for the synthesis of RNA probes complementary to rne mRNA. Plasmid pT7meFL is a derivative of pOK12 (Vieira and Messing 1991) in which a 3.6-kb $B c l I-B s t \mathrm{BI}$ fragment of the rne gene and a $0.84-\mathrm{kb}$ NarI-BclI fragment of pACYCl84 (Rose 1988b) have been inserted between the BgIII and $B a m H I$ sites of the pOK 12 polylinker such that the pACYCl84 fragment is proximal to the $\mathrm{T} 7$ promoter. Plasmid pT7rne5' was constructed by inserting a $2.1-\mathrm{kb}$ PstIHpaI fragment of pRNE101 between the PstI and HincII sites of pUC21 (Vieira and Messing 1991). Plasmid pT7rne302, used as a template for the synthesis of an RNA probe complementary to rne302 mRNA, was constructed by inserting a $1.7-\mathrm{kb}$ HindIIIDraI fragment containing the entire rne302 gene of pRNE302 between the HindIII and SmaI sites of plasmid Bluescript $\mathrm{KS}(+)$ (Stratagene). The F-based lacI ${ }^{\mathrm{a}}$ plasmid pRJM386 was obtained as a gift from D. Chattoraj (National Cancer Institute, Bethesda, MD). The control plasmid pLG339 has been described previously (Stoker et al. 1982).

\section{Ribonuclease protection assays}

Radiolabeled RNA probes complementary to nucleotides 1-1257 and 1-3466 of the rne transcript were synthesized in vitro by transcription of pT7rne $5^{\prime}$ or pT7rneFL DNA with T7 RNA polymerase (Krupp 1988). For synthesis of the probe complementary to nucleotides 2890-3466, pT7rneFL DNA was linearized with $B a m H I$ prior to in vitro transcription. The template for preparing a radiolabeled RNA probe complementary to rne302 mRNA was pT7me302 linearized with XhoI. The specific radioactivity of the $\left[\alpha^{32} \mathrm{P}\right]$ ATP used for labeling was adjusted to give incorporation, on average, of one ${ }^{32} \mathrm{P}$ atom per RNA molecule. Samples of total cellular RNA (5 $\mu \mathrm{g})$ were lyophilized with $25 \mathrm{nCi}$ of probe and resuspended in $20 \mu \mathrm{l}$ of hybridization buffer (40 mM PIPES at pH 6.4, 1 mM EDTA, 80\% formamide). The samples were heated to $90^{\circ} \mathrm{C}$ for $4 \mathrm{~min}$ and then incubated overnight at $45^{\circ} \mathrm{C}$. Subsequently, $200 \mu \mathrm{l}$ of RNase $T_{1}$ solution (500 units) in $10 \mathrm{~mm}$ Tris- $\mathrm{HCl}(\mathrm{pH} 7.5), 300$ $\mathrm{mM} \mathrm{NaCl}$, and $5 \mathrm{~mm}$ EDTA was added, and the samples were incubated at $30^{\circ} \mathrm{C}$ for $1 \mathrm{hr}$. The ribonuclease digestion was stopped by addition of $225 \mu \mathrm{l}$ of guanidinium isothiocyanate solution (4 M guanidinium isothiocyanate, $25 \mathrm{~mm}$ sodium citrate, $0.5 \%$ sodium $N$-lauroylsarcosine), tRNA $(25 \mu \mathrm{g})$ was added, and the RNA was precipitated with isopropanol $(450 \mu \mathrm{l})$. Finally, the samples were dissolved in $10 \mu$ l of loading buffer (12.5 mM EDTA, 5\% glycerol, $0.1 \%$ SDS, $0.03 \%$ bromphenol blue, $0.03 \%$ xylene cyanol) and electrophoresed on a nondenaturing $4 \%$ polyacrylamide or $0.7 \%$ agarose gel. Band intensities were quantitated using a Molecular Dynamics PhosphorImager.

\section{Western blotting}

To prepare E. coli protein samples for Western blotting, cells were heated to $100^{\circ} \mathrm{C}$ for $5 \mathrm{~min}$ in loading buffer $162 \mathrm{~mm}$ Tris$\mathrm{HCl}$ at $\mathrm{pH} 6.8,2 \%$ SDS, $10 \%$ glycerol, $0.001 \%$ bromophenol blue) and then analyzed for total protein content using the BCA assay (Stoscheck 1990). 2-Mercaptoethanol was added to a final concentration of $5 \%$, and $5 \mu \mathrm{g}$ of each sample was loaded onto an SDS-polyacrylamide gel $(5 \%)$ for electrophoresis. Each gel was blotted onto a Hybond-C membrane (Amersham) and probed with a polyclonal RNase E antibody directed against a protein fragment comprising RNase E amino acid residues 182-
814. RNase E-specific bands were detected using an Amersham ECL (enhanced chemiluminescence) kit. After exposing the blot to X-ray film, band intensities were quantitated using an LKB Ultroscan laser densitometer.

\section{Other techniques}

Bacterial cultures for RNA isolation, protein extraction, and $\beta$-galactosidase activity assays were grown to mid-log phase at $37^{\circ} \mathrm{C}$ in LB medium unless otherwise indicated. RNA isolation, primer extension reactions, and $\beta$-galactosidase assays were performed as described (Chomczynski 1993; Jain and Kleckner 1993). For mRNA half-life measurements, samples of total cellular RNA were isolated periodically from transcriptionally arrested cells, beginning $1 \mathrm{~min}$ after rifampicin addition $(200 \mu \mathrm{g}$ ) $\mathrm{ml}$ to allow completion of the last round of transcription, and mRNA decay rates were determined by least-squares analysis of RNase protection data. Sequencing reactions were carried out using a Sequenase kit (U.S. Biochemical) according to the protocol supplied by the manufacturer. The DNA oligonucleotide used for primer extension and sequencing reactions was $5^{\prime}$ TAACTGCCTGAAAGATCA- ${ }^{\prime}$ '. Northern blotting and oligonucleotide-directed mutagenesis were performed as described (Sambrook et al. 1989; Kunkel et al. 1991).

\section{Acknowledgments}

We are grateful to Li-How Chen and Ibuki Kimura for preparing antibodies against RNase E and to Dana Boyd for helpful discussions. We also thank Todd Arnold, Angela Bricker, Li-How Chen, Ite Laird-Offringa, and Cheryl Wellington for technical advice. This research was supported by a grant to J.G.B. from the National Institutes of Health (GM35769) and by a Faculty Research Award to J.G.B. from the American Cancer Society (FRA419).

The publication costs of this article were defrayed in part by payment of page charges. This article must therefore be hereby marked "advertisement" in accordance with 18 USC section 1734 solely to indicate this fact.

\section{References}

Apirion, D. 1978. Isolation, genetic mapping, and some characterization of a mutation in Escherichia coli that affects the processing of ribonucleic acids. Genetics 90: 659-671.

Babitzke, P. and S.R. Kushner. 1991. The Ams /altered mRNA stability) protein and ribonuclease $\mathrm{E}$ are encoded by the same structural gene of Escherichia coli. Proc. Natl. Acad. Sci. 88: $1-5$.

Belasco, J.G. 1993. mRNA degradation in prokaryotic cells: An overview. In Control of messenger RNA stability, pp. 3-12. Academic Press, San Diego, CA.

Carpousis, A.J., G. Van Houwe, C. Ehretsmann, and H.M. Krisch. 1994. Co-purification of E. coli RNase E and PNPase: Evidence for a specific association between two enzymes important in RNA processing and degradation. Cell 76: 889900.

Casarégola, S., A. Jacq, D. Laoudj, G. McGurk, S. Margarson, M. Tempete, V. Norris, and I.B. Holland. 1992. Cloning and analysis of the entire Escherichia coli ams gene: ams is identical to hmp1 and encodes a $114 \mathrm{kDa}$ protein that migrates as a $180 \mathrm{kDa}$ protein. J. Mol. Biol. 228: 30-40.

Chen, L.-H., S.A. Emory, A.L. Bricker, P. Bouvet, and J.G. Belasco. 1991. Structure and function of a bacterial mRNA stabilizer: Analysis of the $5^{\prime}$ untranslated region of ompA 
mRNA. J. Bacteriol. 173: 4578-4586.

Chomczynski, P. 1993. A reagent for the single-step simultaneous isolation of RNA, DNA, and proteins from cell and tissue samples. BioTechniques 15: 532-537.

Claverie-Martin, F., M.R. Diaz-Torres, S.D. Yancey, and S.R. Kushner. 1989. Cloning of the altered mRNA stability (ams) gene of Escherichia coli K-12. J. Bacteriol. 171: 5479-5486.

- 1991. Analysis of the altered mRNA stability (ams) gene from Escherichia coli. J. Biol. Chem. 266: 2843-2851.

Cormack, R.S., J.L. Genereaux, and G.A. Mackie. 1993. RNase E activity is conferred by a single polypeptide: Overexpression, purification, and properties of the ams $/ r n e / h m p 1$ gene product. Proc. Nat1. Acad. Sci. 90: 9006-9010.

Ehretsmann, C.P., A.J. Carpousis, and H.M. Krisch. 1992. Specificity of Escherichia coli endoribonuclease RNase E: In vivo and in vitro analysis of mutants in a bacteriophage T4 mRNA processing site. Genes \& Dev. 6: 149-159.

Hansen, M.J., L.-H. Chen, M.L.S. Fejzo, and J.G. Belasco. 1994. The ompA 5' untranslated region impedes a major pathway for mRNA degradation in Escherichia coli. Mol. Microbiol. 12: 707-716.

He, L., F. Soderbom, E.G.H. Wagner, U. Binnie, N. Binns, and M. Masters. 1993. PcnB is required for the rapid degradation of RNA I, the antisense RNA that controls the copy number of ColE1-related plasmids. Mol. Microbiol. 9: 1131-1142.

Jain, C. 1993. New improved lacZ gene fusion vectors. Gene 133: 99-102.

Jain, C. and N. Kleckner. 1993. IS10 mRNA stability and steady state levels in Escherichia coli: Indirect effects of translation and role of $r n e$ function. Mol. Microbiol. 9: 233-247.

Jin, D.J., R.R. Burgess, J.P. Richardson, and C.A. Gross. 1992. Termination efficiency at rho-dependent terminators depends on kinetic coupling between RNA polymerase and rho. Proc. Natl. Acad. Sci. 89: 1453-1457.

Klug, G., C.W. Adams, J.G. Belasco, B. Doerge, and S.N. Cohen. 1987. Biological consequences of segmental alterations in mRNA stability: Effect of deletion of the intercistronic hairpin-loop region of the $R$. capsulatus puf operon. EMBO $J$. 6: $\mathbf{3 5 1 5 - 3 5 2 0 .}$

Krupp, G. 1988. RNA synthesis: Strategies for the use of bacteriophage RNA polymerase. Gene 72: 75-89.

Kunkel, T.A., K. Bebenek, and J. McClary. 1991. Efficient sitedirected mutagenesis using uracil-containing DNA. Methods Enzymol. 204: 125-139.

Lin-Chao, S., T.-T. Wong, K.J. McDowall, and S.N. Cohen. 1994. Effects of nucleotide sequence on the specificity of rne-dependent and RNase E-mediated cleavages of RNA I encoded by the pBR322 plasmid. J. Biol. Chem. 269: 10797-10803.

Lundberg, U., A. von Gabain, and Ö. Melefors. 1990. Cleavages in the $5^{\prime}$ region of the ompA and bla mRNA control stability: Studies with an $E$. coli mutant altering mRNA stability and a novel endoribonuclease. EMBO I. 9: 2731-2741.

McDowall, K.J., S. Lin-Chao, and S.N. Cohen. 1994. A + U content rather than a particular nucleotide order determines the specificity of RNase E cleavage. I. Biol. Chem. 269: 1079010796.

Melefors, Ö. 1991. "The mechanism of ompA mRNA degradation in E. coli." Ph.D. thesis, Karolinska Institute, Stockholm, Sweden.

Melefors, Ö., and A. von Gabain. 1991. Genetic studies of cleavage-initiated mRNA decay and processing of ribosomal $9 \mathrm{~S}$ RNA show that the Escherichia coli ams and rne loci are the same. Mol. Microbiol. 5: 857-864.

Miller, J.H. 1972. Experiments in molecular genetics. Cold Spring Harbor Laboratory, Cold Spring Harbor, New York.

Mudd, E.A. and C.F. Higgins. 1993. Escherichia coli endoribo- nuclease RNase E: Autoregulation of expression and sitespecific cleavage of mRNA. Mol. Microbiol. 9: 557-568.

Mudd, E.A., H.M. Krisch, and C.F. Higgins. 1990. RNase E, an endoribonuclease, has a general role in the chemical decay of E. coli mRNA: Evidence that $r n e$ and ams are the same genetic locus. Mol. Microbiol. 4: 2127-2135.

Newbury, S.F., N.H. Smith and C.F. Higgins. 1987. Differential mRNA stability controls relative gene expression within a polycistronic operon. Cell 51: 1131-1143.

Ono, M. and M. Kuwano. 1979. A conditional lethal mutation in an Escherichia coli strain with a longer chemical lifetime of mRNA. J. Mol. Biol. 129: 343-357.

Rose, J.K., R.D. Mosteller, and C. Yanofsky. 1970. Tryptophan messenger ribonucleic acid elongation rates and steady-state levels of tryptophan operon enzymes under various growth conditions. J. Mol. Biol. 51: 541-550.

Rose, R.E. 1988a. The nucleotide sequence of pACYC177. Nucleic Acids Res. 16: 356.

. 1988b. The nucleotide sequence of pACYC184. Nucleic Acids Res. 16: 355.

Sambrook, J., E.F. Fritsch, and T. Maniatis. 1989. Molecular cloning: A laboratory manual. Cold Spring Harbor Laboratory Press, Cold Spring Harbor, New York.

Simons, R.W., F. Houman, and N. Kleckner. 1987. Improved single and multicopy lac-based cloning vectors for protein and operon fusions. Gene 53: 85-96.

Stoker, N.G., N.F. Fairweather, and B.G. Spratt. 1982. Versatile low-copy-number vectors for cloning in Escherichia coli. Gene 18: 335-341.

Stoscheck, C.M. 1990. Quantitation of protein. Methods Enzy. mol. 182: 50-68.

Taraseviciene, L., A. Miczak, and D. Apirion. 1991. The gene specifying RNase E ( $r n e$ ) and a gene affecting mRNA stability (ams) are the same gene. Mol. Microbiol. 5: 851-855.

Vieira, J. and J. Messing. 1991. New pUC-derived cloning vectors with different selectable markers and DNA replication origins. Gene 100: 189-194.

Wang, R.F. and S.R. Kushner. 1991. Construction of versatile low-copy-number vectors for cloning, sequencing and gene expression in Escherichia coli. Gene 100: 195-199.

Xu, F., S. Lin-Chao, and S.N. Cohen. 1993. The Escherichia coli $p c n B$ gene promotes adenylation of antisense RNAI of ColEl-type plasmids in vivo and degradation of RNAI decay intermediates. Proc. Natl. Acad. Sci. 90: 6756-6760.

Yarchuk, O., N. Jacques, J. Guillerez, and M. Dreyfus. 1992. Interdependence of translation, transcription and mRNA degradation in the lacZ gene. I. Mol. Biol. 226: 581-596. 


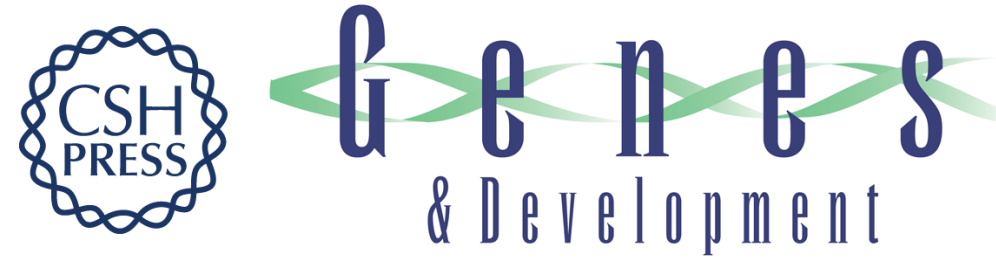

\section{RNase E autoregulates its synthesis by controlling the degradation rate of its own mRNA in Escherichia coli: unusual sensitivity of the rne transcript to RNase E activity.}

C Jain and J G Belasco

Genes Dev. 1995, 9:

Access the most recent version at doi:10.1101/gad.9.1.84

References This article cites 37 articles, 11 of which can be accessed free at: http://genesdev.cshlp.org/content/9/1/84.full.html\#ref-list-1

License

Email Alerting Service

Receive free email alerts when new articles cite this article - sign up in the box at the top right corner of the article or click here.

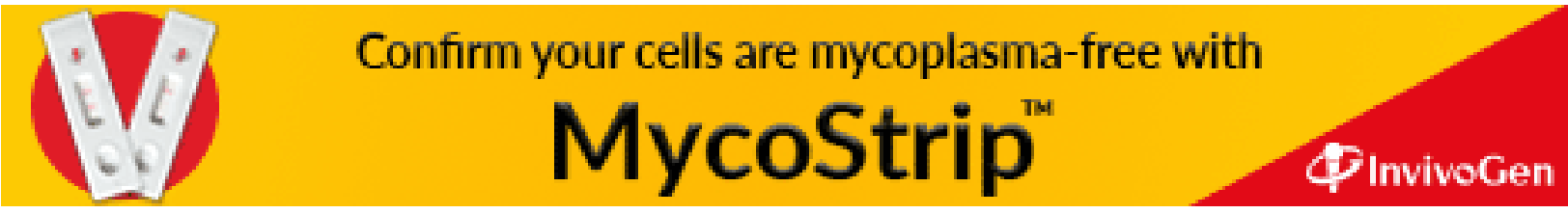

